\title{
Santa Ana Fire Department Experiment at 1315 South Bristol, July 14, 1994
}

A.D. Putorti Jr.

W.D. Walton

W.H. Twilley

S. Deal

Fire Safety Engineering Division

Building and Fire Research Laboratory

and

J.C. Albers

Fire Safety Division

City of Santa Ana Fire Department

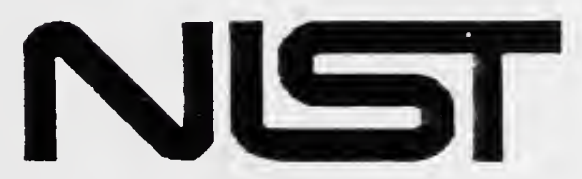

\section{United States Department of Commerce}

Technology Administration

National Institute of Standards and Technology 



\section{U.S. DEPARTMENT OF COMMERCE}

NATIONAL INSTITUTE OF STANDARDS AND ' $E$ ECHNOLOGY

Gaithersburg, MD 20899

\section{REPORT OF TEST \\ FR 3995}

August 31, 1994

Santa Ana Fire Department Experiment at 1315 South Bristol July 14, 1994

A.D. Putorti Jr, W.D. Walton, W.H. Twilley, S. Deal

Building and Fire Research Laboratory National Institute of Standards and Technology

U.S. Depa tment of Commerce

Gaithersburg, MD 20899

and

J.C. Albers

Fire Safety Division

City of Santa Ana Fire Department

Santa Ana, CA 92706 



\section{Introduction}

The Santa Ana Fire Department of Santa Ana, California conducted a series of fire experiments in residences on South Bristol Street in the City of Santa Ana in July, 1994. NIST provided technical support, consisting of measurements of fire phenomena, to the fire department during these experiments.

The experiment to be addressed in this report occurred on July 14, 1994, at 1315 South Bristol Street. The measurements included: temperatures within various rooms, the velocity and temperature of outflowing gases, smoke detector activation time, sprinkler activation times, and time to full room involvement. Data were recorded every 5 seconds with a computerized acquisition system.

\section{Structure}

The building used for the fire experiment was a vacant one story single family dwelling. The building was of wood frame construction, with gypsum board interior walls and ceiling, and stucco over wire mesh and paper exterior walls. The floors throughout the building, with the exception of the kitchen and bathroom, were constructed of hardwood. The floors in the kitchen and bathroom were covered with vinyl flooring.

The building had no basement, but rather a ventilated crawl space. The building was covered with a pitched roof, consisting of asphalt shingles over redwood planks.

The layout of the building is shown in Figures 1 and 2, along with interior dimensions. There were three bedrooms, a bathroom, living room, kitchen, and garage. In order to simulate a second story bedroom, a section of roof was removed and $r$ room was added above the living room. The addition was of wood frame construction, with the interior walls and ceiling consisting of fire rated $15.9 \mathrm{~mm}$ ( 0.625 in nominal) thick gypsum board. There was no exterior covering over the wood members of the second story room.

\section{Smoke Detector}

A smoke detector was installed in the hallway outside of the bedrooms in accordance with NFPA 74. The detector was a single station, battery powered, UL listed, ionization type smoke detector. The activation time for the smoke detector was recorded manually by an observer equipped with a stop watch. The location of the smoke detector is shown in Figure 3. 


\section{Sprinklers}

In order to measure the activation time of typical residential type sprinklers, one pendent sprinkler was installed in the ceiling of the living room, and one sidewall sprinkler was installed on the front wall of the living room. It should be noted that an actual residential sprinkler system installed according to NFPA 13D would require more than one pendent or sidewall sprinkler to be installed in the living room.

The sprinklers had glass bulb elements with activation temperatures of $68^{\circ} \mathrm{C}\left(155^{\circ} \mathrm{F}\right)$. Each sprinkler was connected to a pressure switch wi.h copper tubing. The tubing was pressurized with approximately $210 \mathrm{kPa}$ (30 psi) of air pressure. When a sprinkler actuated, the signal was recorded on the data acquisition system, and timed via an indicator light.

In addition to the sprinklers installed for the measurement of activation time, two additional sidewall sprinklers, attached to a manually controlled water supply, were installed in the front wall of the fire room for experimental safety. Water was applied through the sprinklers for approximately 15 seconds at the end of the experiment prior to manual fire fighting which extinguished the fire.

The locations of the various sprinklers are shown in Figure 3.

\section{Temperature Measurement}

The temperatures were measured with $0.51 \mathrm{~mm}(0.02 \mathrm{in})$ nominal diameter bare bead, type $\mathrm{K}$ thermocouples. Floor to ceiling thermocouple arrays were located in the living room, hallway, and second floor room as shown in Figures 3 and 4 . The elevations of the thermocouples above the floor are given in Table 1 for the living room, and in Table 2 for the hallway and second floor.

Thermocouples were located within $20 \mathrm{~mm}(0.79 \mathrm{in})$ of the pendent and sidewall sprinklers used to measure activation time. A thermocouple was located within a sheet of crumpled newspaper located on the floor near the television set as shown in Figure 3. This thermocouple was used to detect ignition of the newspaper, an indication that full room involvement had occurred.

An array of thermocouples was located in the centerline of the open front window of the second story room. The elevations of the thermocouples, as measured from the top of the window are listed in Table 3.

The uncertainty in temperature measurement is $\pm 2.2^{\circ} \mathrm{C}\left( \pm 4.0^{\circ} \mathrm{F}\right)$ as derived from the thermocouple wire manufacturer. The uncertainties in the thermocouple locations are estimated at $\pm 0.01 \mathrm{~m}(0.4 \mathrm{in}$.) 


\section{Velocity Measurement}

The gas velocity in the front second story window was measured with a bi-directional probe connected to a differential pressure transducer. The bi-directional probe was located $0.15 \pm 0.01 \mathrm{~m}$ below the top of the window approximately $25 \mathrm{~mm}(0.98 \mathrm{in})$ from a thermocouple. The uncertainty for the gas velocity measurements is $\pm 0.1 \mathrm{~m} / \mathrm{s}(0.3$ $\mathrm{ft} / \mathrm{s}$ ) as derived from manufacturer data for the differential pressure transducer.

\section{Fuel Load}

The fire room was furnished by the Santa Ana Fire Department to simulate high fuel load conditions. The furnishings consisted of two wood frame bunk beds (mattresses without box springs), a double bed (mattress and box spring), pillows, two couches, a television set, a lamp shade, and assorted articles of clothing. The total mass of the contents was $552.0 \mathrm{~kg}(1217 \mathrm{lb})$ with an uncertainty of $10 \%$ estimated for the scale used in the experiments. The masses of the individual components are listed in Table 4. Figure 5 shows the location of the furniture in the room.

In addition to the contents of the room discussed above, there was an ignition source. The ignition source for the fire was a plastic waste basket with nominal overall dimensions of $0.255 \mathrm{~m}$ high by $0.255 \mathrm{~m}$ wide by $0.188 \mathrm{~m}$ deep $(10.0 \times 10.0 \times 7.4$ in.) The waste basket contained a total of eight 2 quart waxed cardboard milk cartons. Two cartons were placed vertically in the basket, with another placed inside each of the two forming two double layered vertically oriented open cartons. Inside each of the vertical cartons was placed the torn pieces, nominally $0.0010 \mathrm{~m}^{2}\left(1.6 \mathrm{in}^{2}\right)$, from two identical cartons. The waste basket was placed between the two sets of bunk beds and ignited by removing one torn piece from each of the two vertical cartons, igniting it, and dropping it into the carton.

\section{Results}

The sequence of events for the experiment is given in Table 5, with an estimated uncertainty of \pm 2 seconds.

The temperatures measured within the living room (fire room) are shown in Figure 6. The data is presented for various distances from the floor in order to simplify the graphs yet show the temperature profile within the room. Due to the failure of the living room thermocouple tree shortly after full room involvement the temperature data is available only up to 120 seconds. The thermocouple near the pendent sprinkler and on the floor in the newspaper, however, operated throughout the experiment. The data from these thermocouples are shown in Figure 7. The data from the thermocouple near the sidewall sprinkler, also shown in Figure 7, ends at approximately 120 seconds due to thermocouple failure. 
The temperatures measured within the hallway are shown in Figure 8. As in the case of the fire room, temperatures are given versus time for selected heights above the floor.

Temperatures measured in the second floor room are graphed in Figure 9. The temperatures of gases entering or leaving through the open window at the front of the room are shown in Figure 10.

The velocity of the outflowing gases measured by the bi-directional probe at the front window of the second story room is shown in Figure 11. 
Table 1. Living room thermocouple elevations.

$\begin{array}{ccc}\text { Thermocouple Number } & \begin{array}{c}\text { Distance } \\ \text { From Floor } \\ (\mathbf{m})\end{array} & \begin{array}{c}\text { Distance } \\ \text { From Floor } \\ (1\end{array} \\ 2.41 & 7.89 \\ 2 & 2.36 & 7.73 \\ 3 & 2.28 & 7.48 \\ 4 & 2.21 & 7.23 \\ 5 & 2.13 & 6.99 \\ 6 & 1.98 & 6.50 \\ 7 & 1.83 & 6.00 \\ 8 & 1.68 & 5.51 \\ 9 & 1.53 & 5.02 \\ 10 & 1.38 & 4.53 \\ 11 & 1.23 & 4.04 \\ 12 & 1.08 & 3.54 \\ 13 & 0.93 & 3.05 \\ 14 & 0.78 & 2.56 \\ 15 & 0.63 & 2.07 \\ 16 & 0.48 & 1.58 \\ 17 & 0.33 & 1.08 \\ 18 & 0.18 & 0.59\end{array}$


Table 2. Hall and second story room thermocouple elevations.

$\begin{array}{ccc}\text { Thermocouple Number } & \begin{array}{c}\text { Distance } \\ \text { From Floor } \\ (\mathbf{m})\end{array} & \begin{array}{c}\text { Distance } \\ \text { From Floor } \\ (\mathrm{ft})\end{array} \\ 1 & 2.42 & 7.92 \\ 2 & 2.37 & 7.76 \\ 3 & 2.29 & 7.51 \\ 4 & 2.22 & 7.27 \\ 5 & 2.14 & 7.02 \\ 6 & 1.99 & 6.53 \\ 7 & 1.84 & 6.04 \\ 8 & 1.69 & 5.55 \\ 9 & 1.54 & 5.05 \\ 10 & 1.39 & 4.56 \\ 11 & 1.24 & 4.07 \\ 12 & 1.09 & 3.58 \\ 13 & 0.94 & 3.08 \\ 14 & 0.79 & 2.59 \\ 15 & 0.64 & 2.10 \\ 16 & 0.49 & 1.61 \\ 17 & 0.34 & 1.12 \\ 18 & 0.19 & 0.62 \\ & & \end{array}$


Table 3. Window thermocouple elevations.

Thermocouple Number Distance From Distance From Top of Window Top of Window

(m)

1

0.15

0.49

2

0.30

0.98

3

0.45

1.48

4

0.60

1.97

5

0.75

2.46

6

0.90

2.95 
Table 4. Fuel load.

$\begin{array}{ccc}\text { Item } & \begin{array}{c}\text { Mass } \\ (\mathbf{k g})\end{array} & \begin{array}{c}\text { Weight } \\ (\mathbf{l b})\end{array} \\ \text { Mattress 1 } & 25.9 & 57.1 \\ \text { Mattress 2 } & 14.5 & 32.0 \\ \text { Mattress 3 } & 14.5 & 32.0 \\ \text { Mattress 4 } & 22.7 & 50.0 \\ \text { Mattress 5 } & 22.2 & 48.9 \\ \text { Box springs } & 23.6 & 52.0 \\ \text { Couch 1 } & 52.2 & 115.1 \\ \text { Shade } & 0.5 & 1.1 \\ \text { Bed clothes } & 19.1 & 42.1 \\ \text { Pillows } & 7.7 & 17.0 \\ \text { Television } & 71.7 & 158.1 \\ \text { Couch 2 } & 54.4 & 120.0 \\ \text { Bed frame (wood) } & 6.4 & 14.1 \\ \text { Bunk bed frames (wood) } & 54.4 & 120.0 \\ \text { Clothing } & 151.0 & 332.9 \\ \text { Total } & \mathbf{5 5 2 . 0} & \mathbf{1 2 1 7 . 0}\end{array}$

Table 5. Sequence of events.

$\begin{array}{ll}\text { Elapsed Time (s) } & \text { Event } \\ 0 & \text { Ignition } \\ 85 & \text { Smoke detector actuation } \\ 100 & \text { Pendent sprinkler actuation } \\ 105 & \text { Sidewall sprinkler actuation } \\ 110 & \text { Transition to full room involvement } \\ 360 & \text { Water application begins }\end{array}$




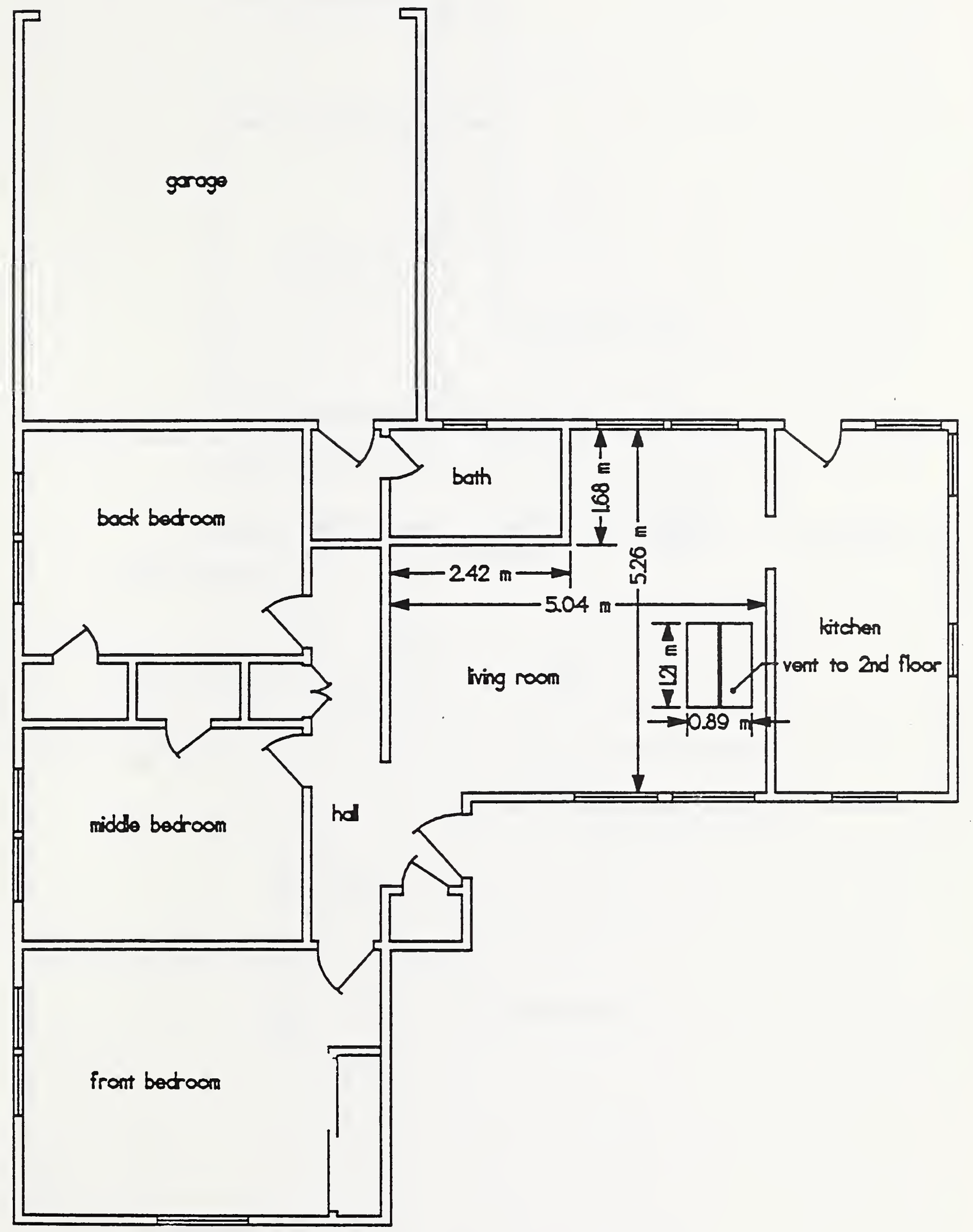

Figure 1. Plan view of the first floor. 


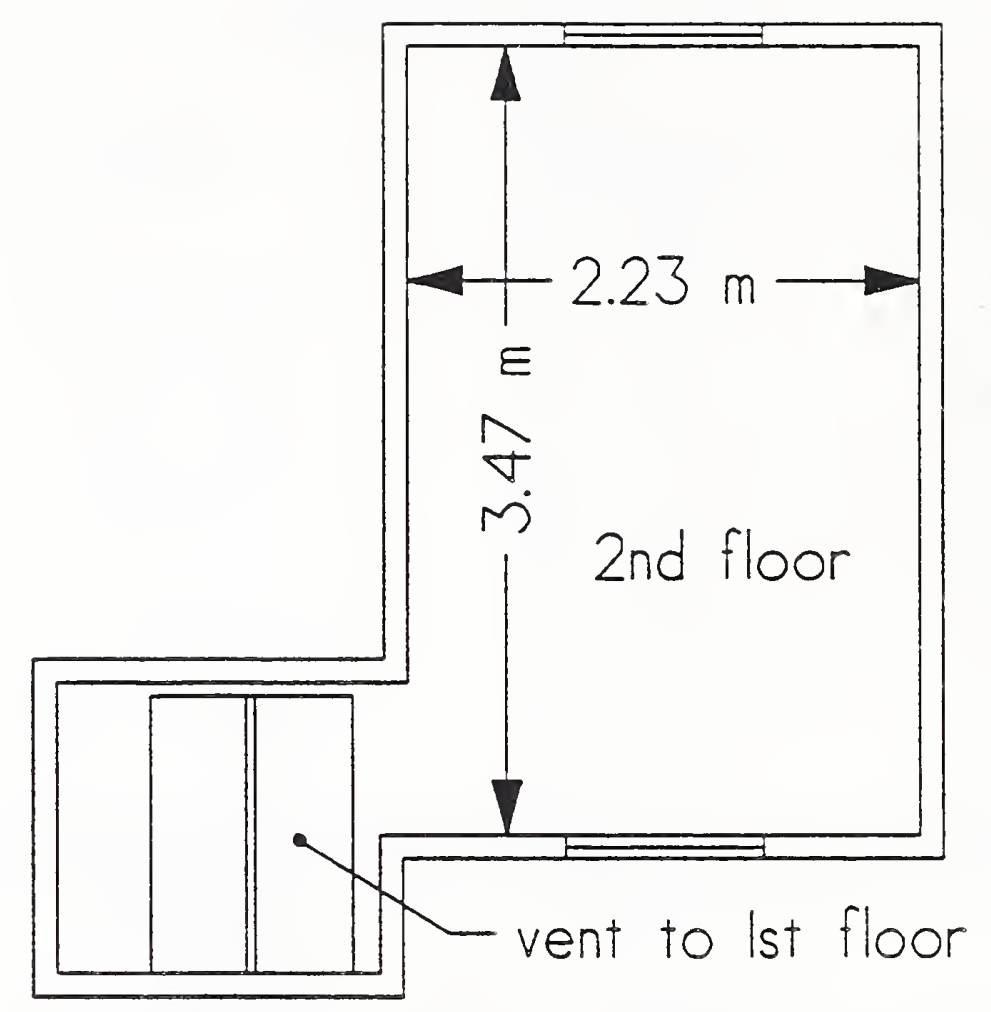

Figure 2. Plan view of the second floor. 


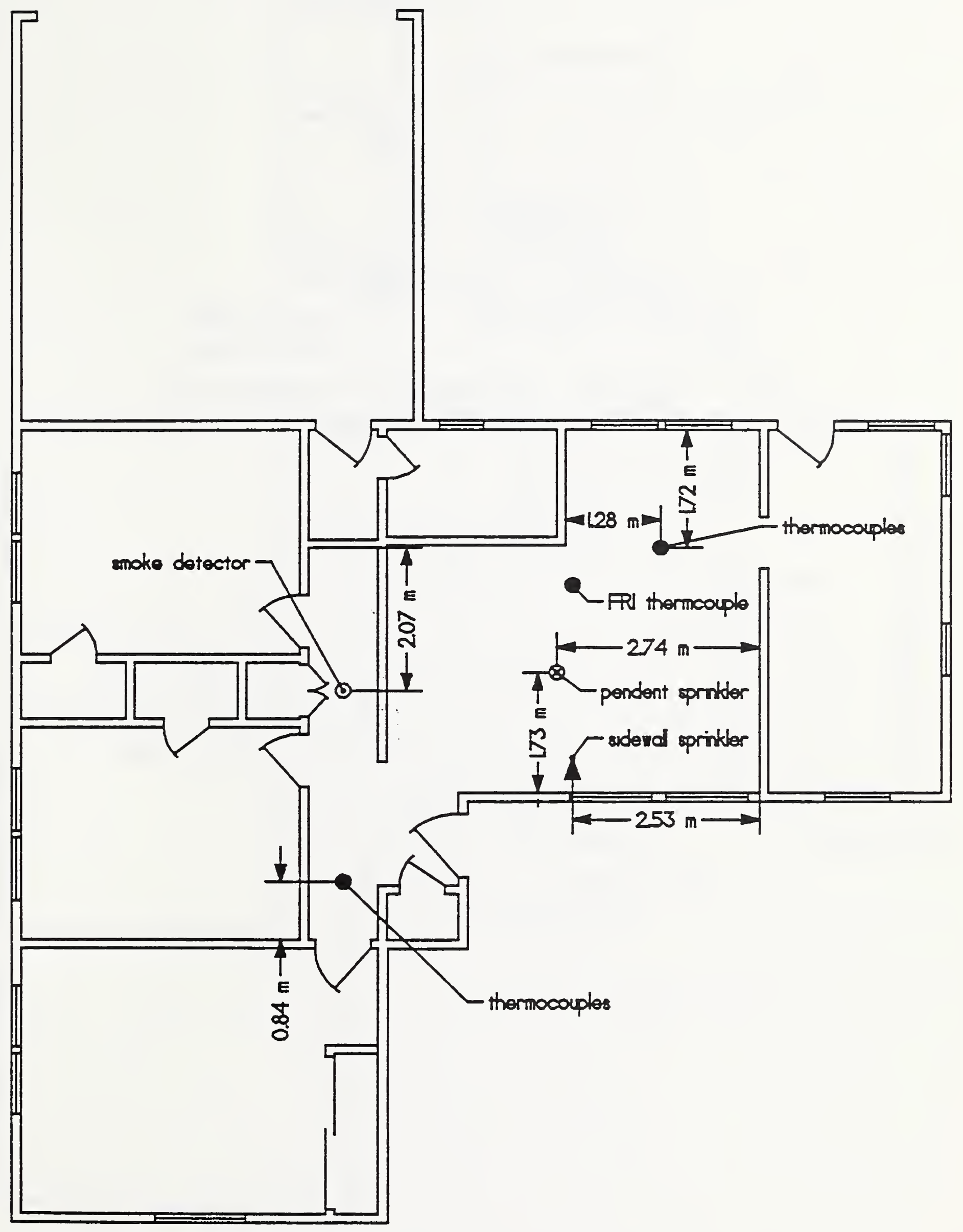

Figure 3. Instrument locations on the first floor. 


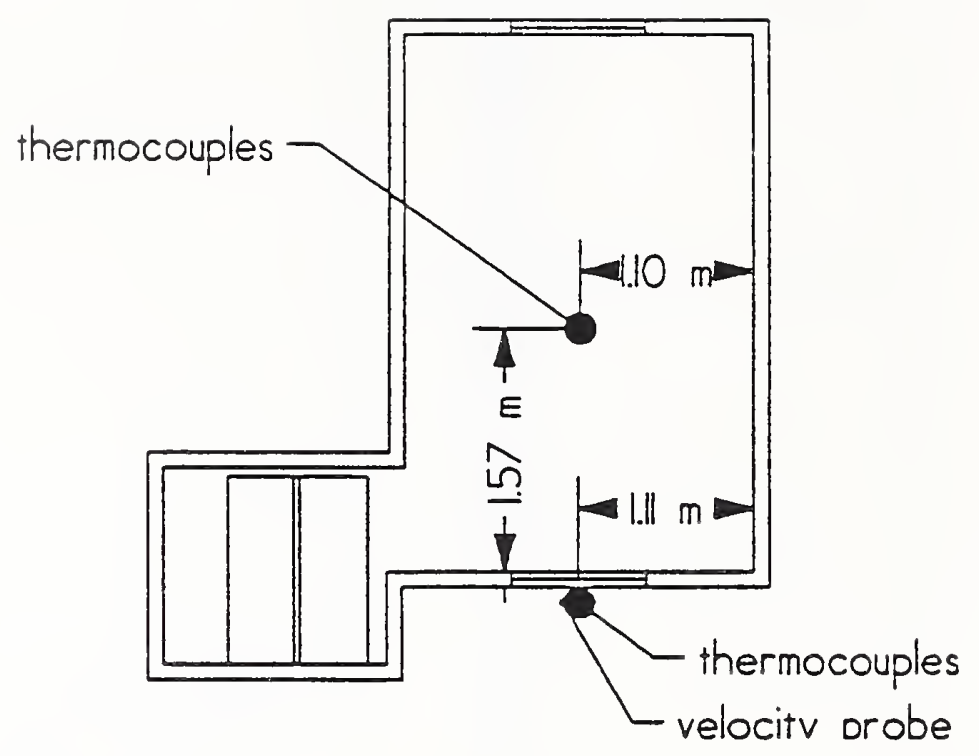

Figure 4. Instrument locations on the second floor. 


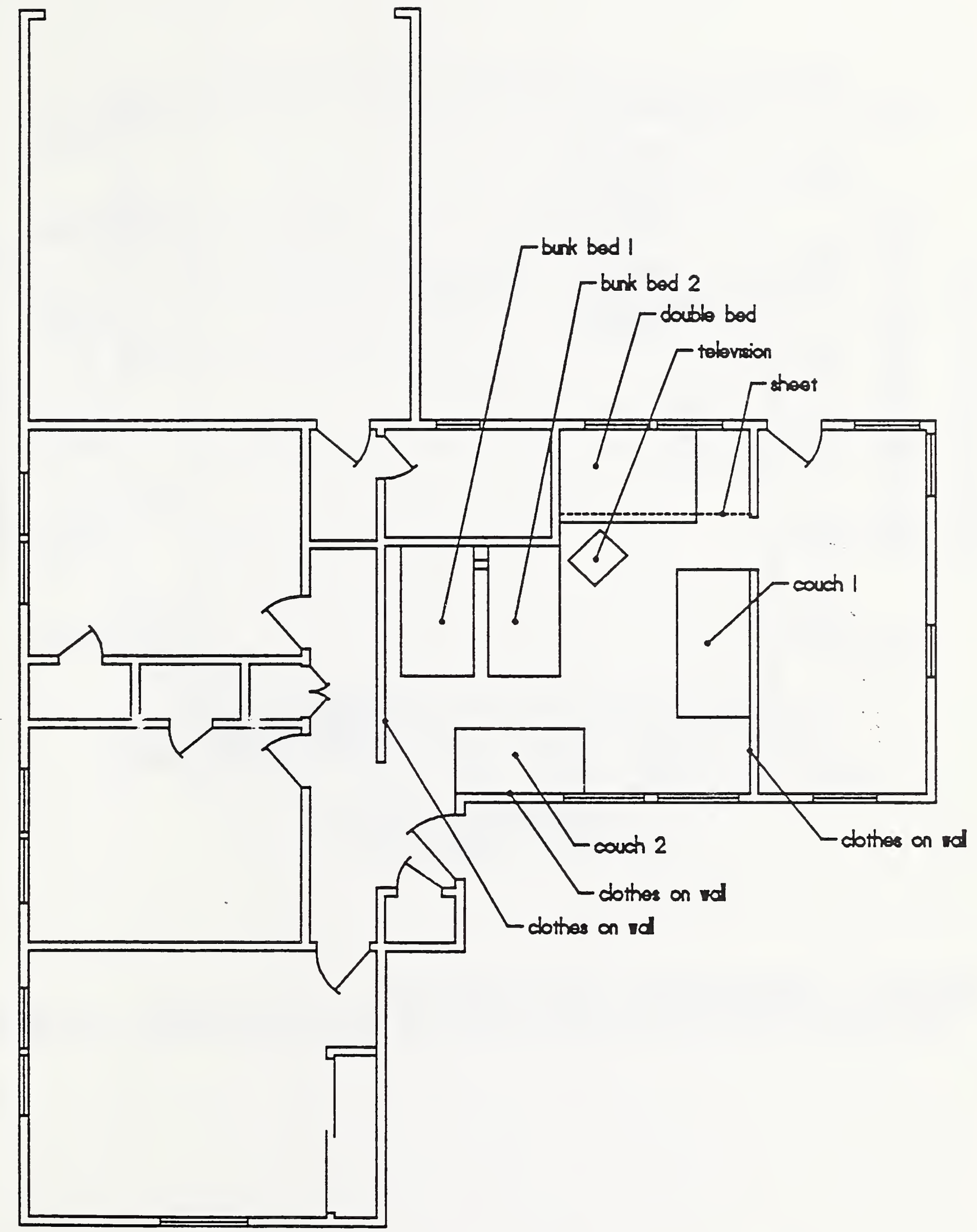

Figure 5. Plan view of fire room with combustible contents. 


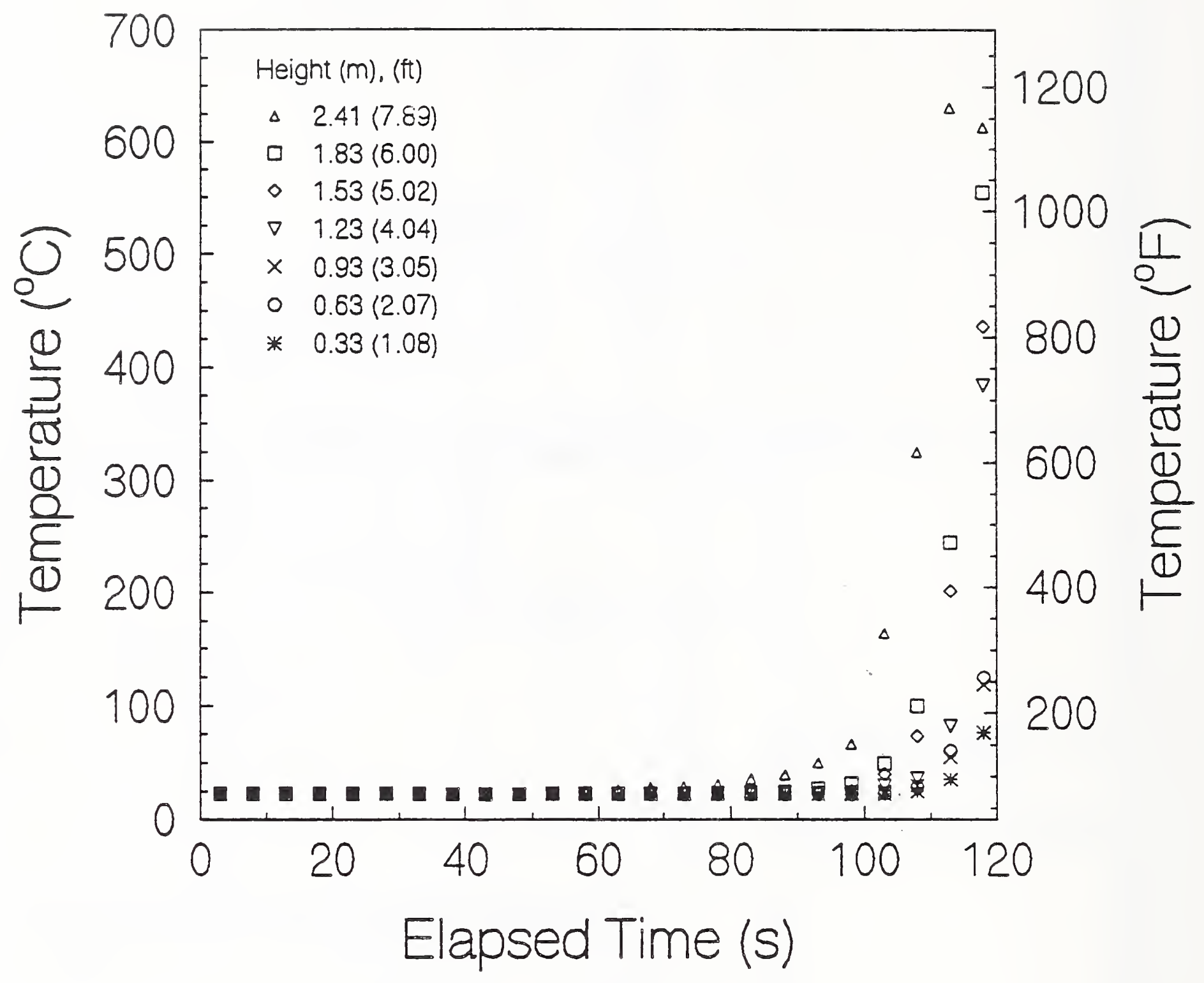

Figure 6. Temperatures in the living room. 


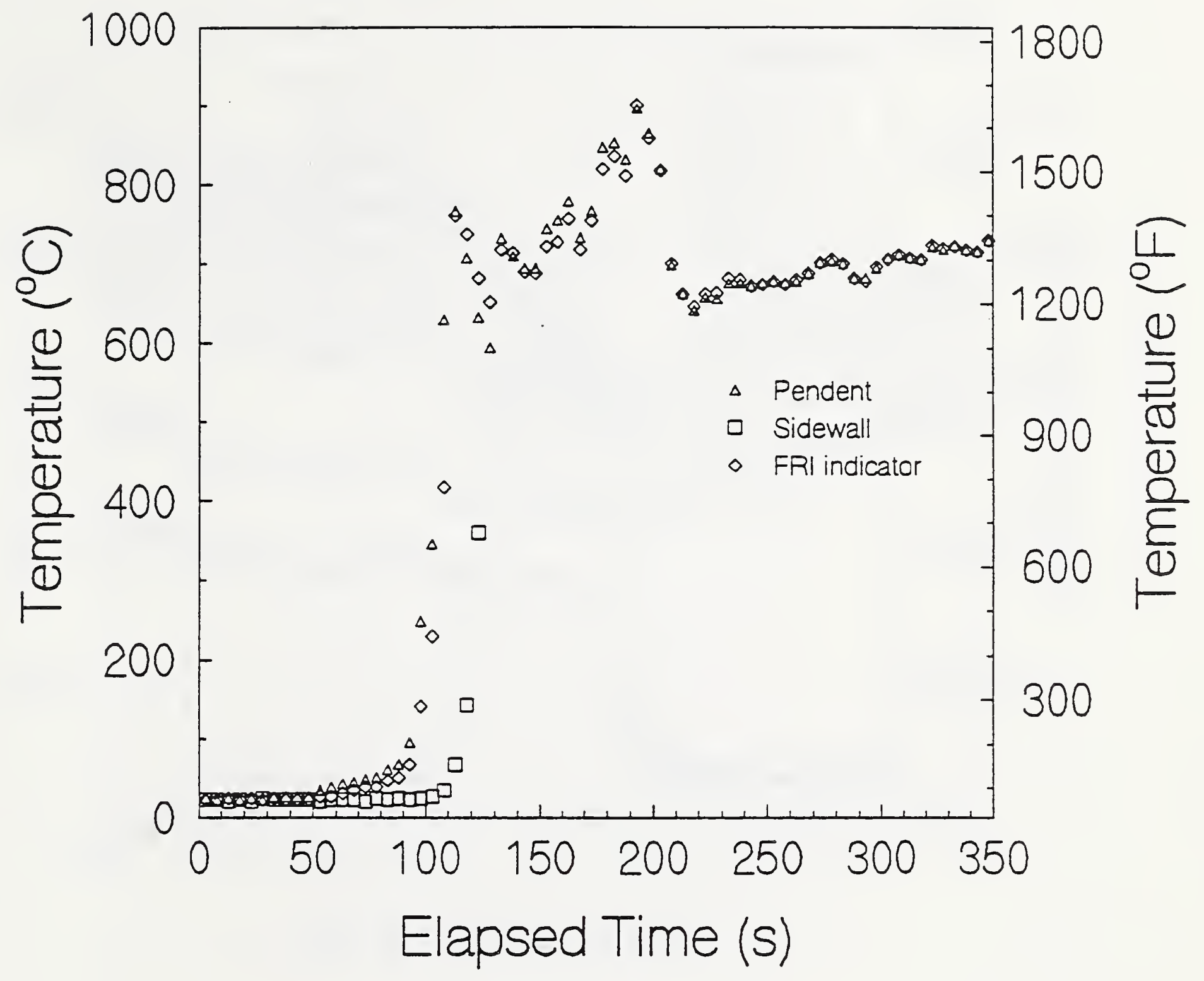

Figure 7. Single thermocouple temperatures within the living room. 


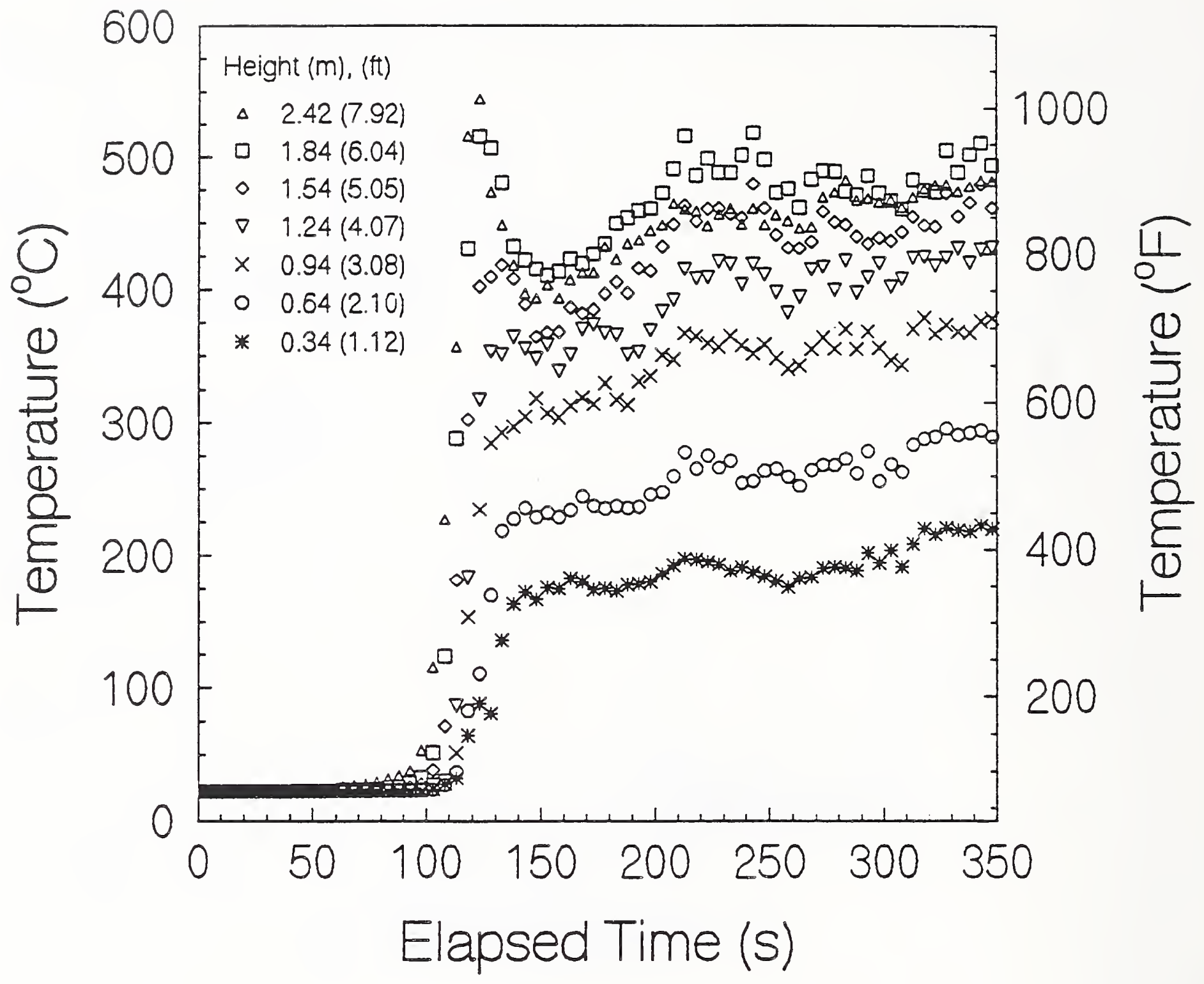

Figure 8. Temperatures in the hall adjacent to the living room. 


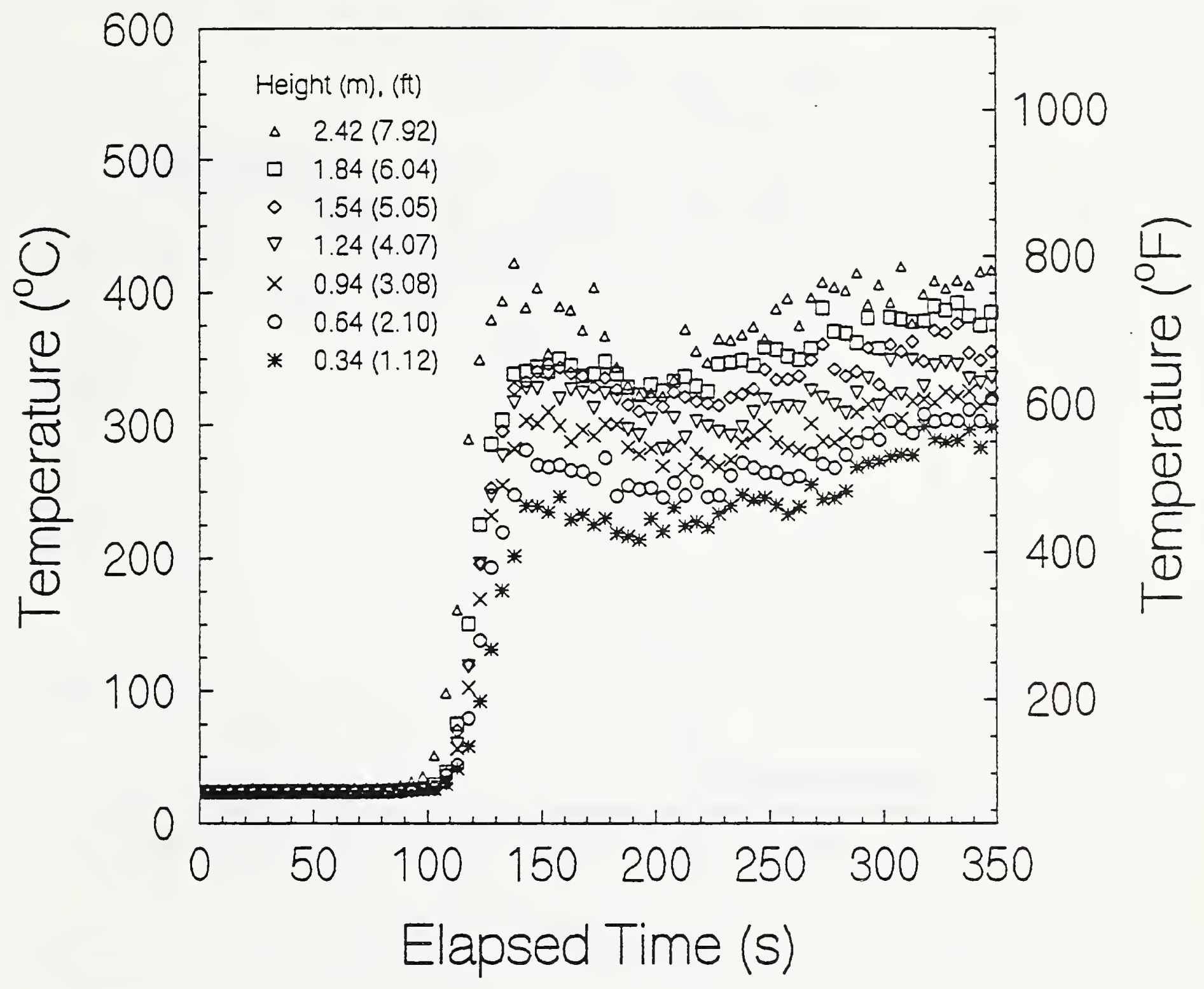

Figure 9. Temperatures in the second story. 


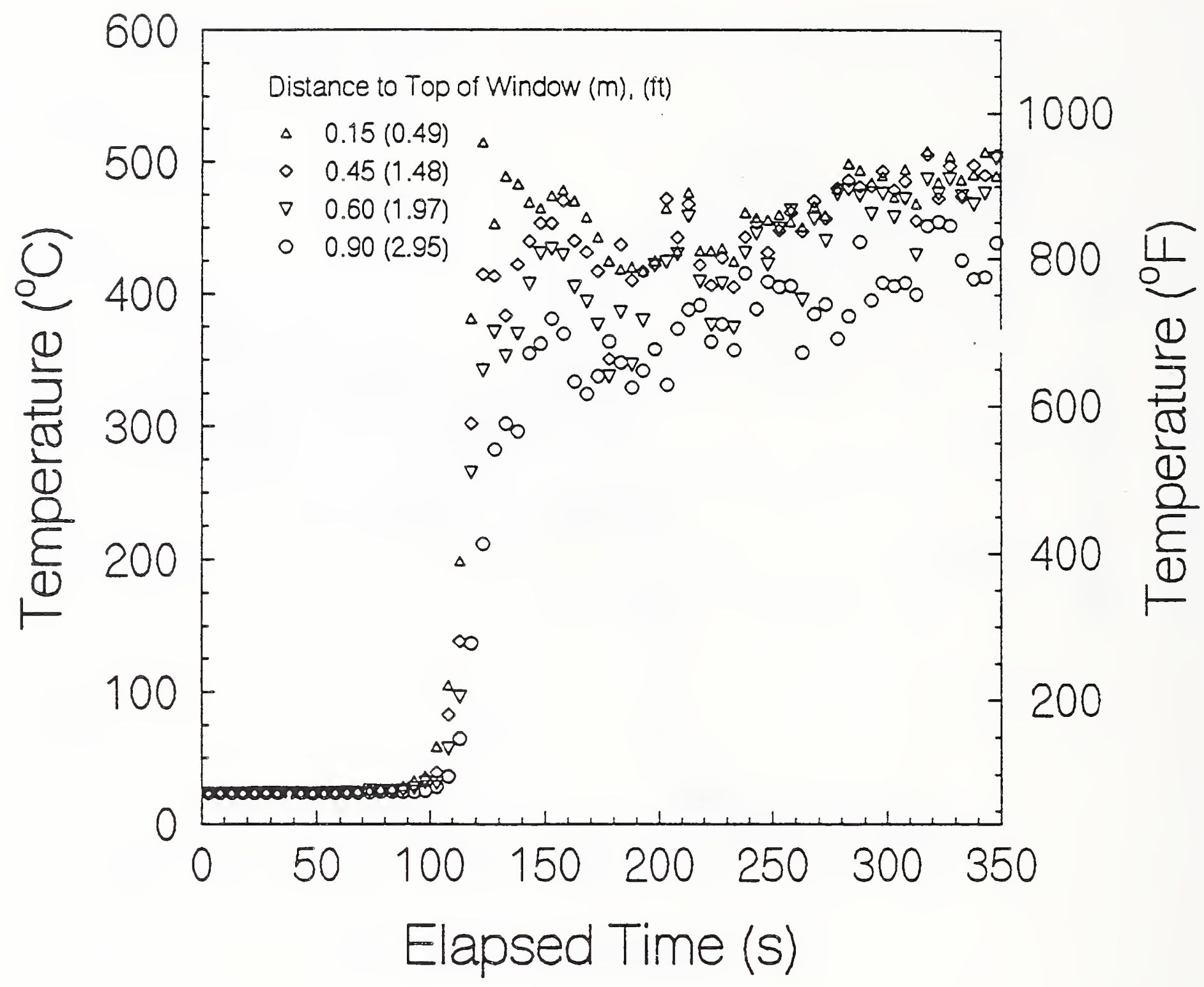

Figure 10. Temperatures in the second story front window. 


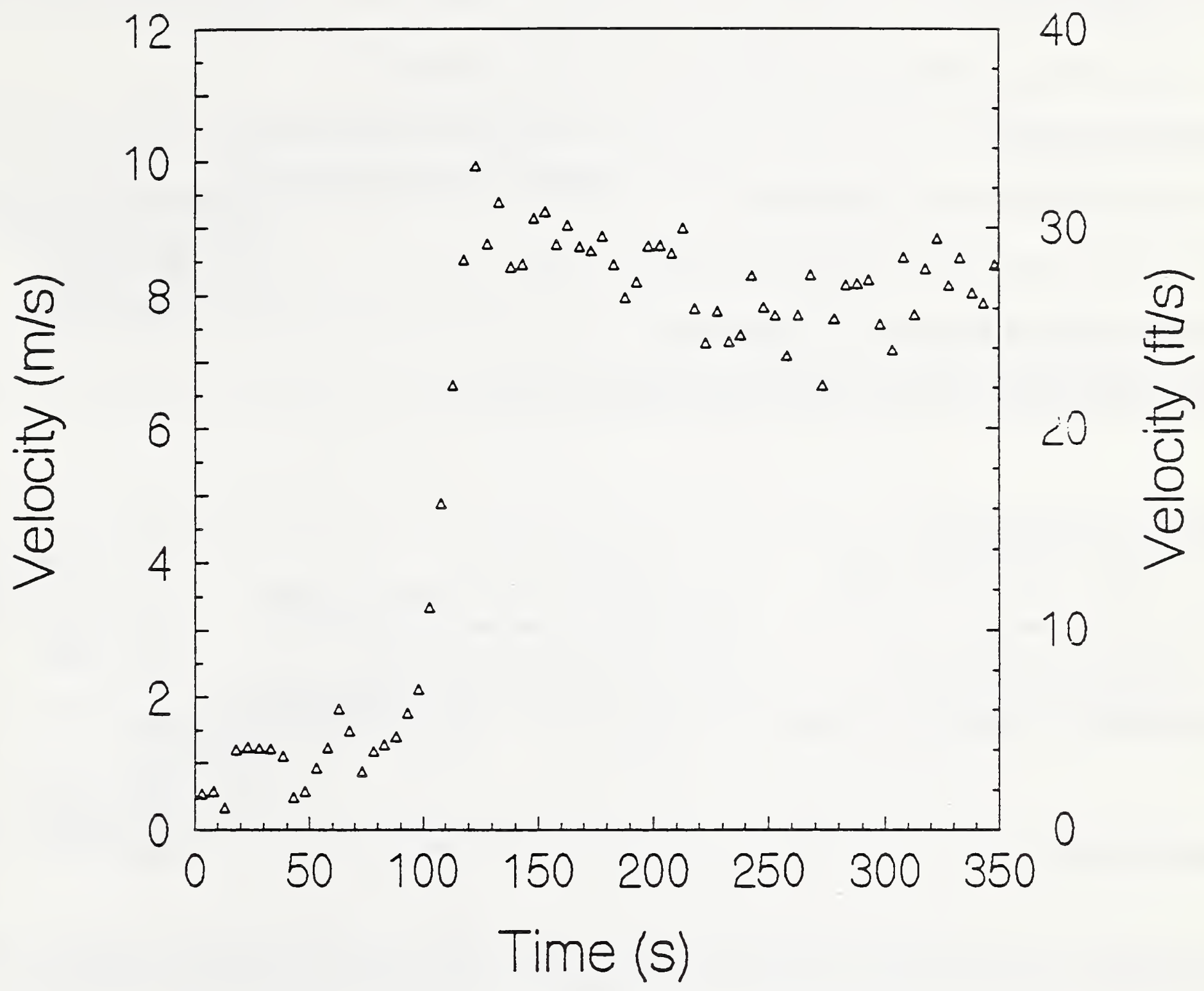

Figure 11. Velocity of the gases at the second story front window. 
NIST- 174

(REV. 6-93)

ADMAN 4.09
U.S. DEPARTMENT OF COMMERCE

NATIONAL INSTITUTE OF STANDARDS AND TECHNOLOGY

MANUSCRIPT REVIEW AND APPROVAL

\begin{tabular}{|l|l}
\hline ERB CONTROL NUMBER & DIVISION
\end{tabular}

PUBLICATION REPORT NUMBER

FR 3995

INSTRUCTIONS: ATTACH ORIGINAL OF THIS FORM TO ONE (1) COPY OF MANUSCRIPT AND SEND TO THE SECRETARY, APPROPRIATE EDITORIAL REVIEW BOARD

TITLE AND SUBTITLE ICITE IN FULL)

Santa Ana Fire Department Experiment at 1315 South Bristol, July 14, 1994

\begin{tabular}{|l|r|r|}
\hline CONTRACT OR GRANT NUMBER & $\begin{array}{r}\text { TYPE OF REPORT ANDIOR PERIOD COVERED } \\
\text { Report of TeSt FR } 3995\end{array}$ \\
\hline
\end{tabular}

AUTHORIS) (LAST NAME, FIRST INITIAL, SECOND INITIAL)

PERFORMING ORGANIZATION (CHECK $(X)$ ONE BOX)

Putorti, Jr., A.D., Walton, W.D., Twilley, W.H., Deal, S., Albers, J.C.

$X$ NIST/GAITHERSBURG

NIST/BOULDER

JLA/BOULDER

LABORATORY AND DIVISION NAMES (FIRST NIST AUTHOR ONLY)

Building \& Fire Research Laboratory, Fire Safety Engineering Division

SPONSORING ORGANIZATION NAME AND COMPLETE ADDRESS (STREET, CITY, STATE. ZIP)

PROPOSED FOR NIST PUBLICATION

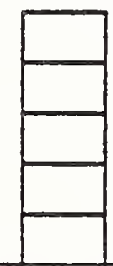

JOURNAL OF RESEARCH (NIST JRES)

J. PHYS. \& CHEM. REF. DATA (JPCRD)

HANDBOOK (NIST HB)

SPECIAL PUBLICATION (NIST SP)

TECHNICAL NOTE (NIST TN)

PROPOSED FOR NON-NIST PUBLICATION (CITE FULLY)

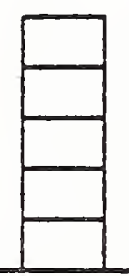

MONOGRAPH (NIST MN)

NATL. STD. REF. DATA SERIES (NIST NSRDS)

FEDERAL INF. PROCESS. STOS. (NIST FIPS)

LIST OF PUBLICATIONS (NIST LP)

NIST INTERAGENCY/INTERNAL REPORT (NISTIR)

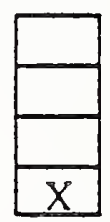

LETTER CIRCULAR BUILDING SCIENCE SERIES PRODUCT STANDARDS OTHER FR
U.S.
FOREIGN

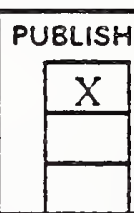

PAPER

DISKETTE (SPECIFY)

OTHER (SPECIFY)

SUPPLEMENTARY NOTES

ABSTRACT (A 2000.CHARACTER OR LESS FACTUAL SUMMARY OF MOST SIGNIFICANT INFORMATION. IF DOCUMENT INCLUDES A SIGNIFICANT BIBLIO GRAPHI LITERATURE SURVEY, CITE IT HERE. SPELL OUT ACRONYMS ON FIRST REFERENCE.) (CONTINUE ON SEPARATE PAGE, IF NECESSARY.)

This report of test addresses a fire experiment conducted on July 14, 1994 in a vacant single family dwelling at 1315 South Bri Street in Santa Ana, Califomia. Fire phenomena measured included: temperatures within various rooms; the velocity and tempera of outflowing cases, smoke detector activation time, sprinkler activation times, and time to full room involvement.

KEY WORDS IMAXIMUM OF 9: 28 CHARACTERS AND SPACES EACH: SEPARATE WITH SEMICOLONS; ALPHABETIC ORDER; CAPITALIZE ONLY PROPER NAMES home fires; single family dwellings; smoke detectors; sprinklers; temperature

AVAILABILITY

\begin{tabular}{|l|}
\hline$X$ \\
\hline$X$ \\
\hline
\end{tabular}
FOR OFFICIAL DISTRIBUTION - DO NOT RELEASE TO NTIS ORDER FROM SUPERINTENDENT OF DOCUMENTS, U.S. GPO, WASHINGTON, OC 20402 ORDER FROM NTIS, SPRINGFIELD, VA 22169 

